\title{
FISCAL EFFECT OF VAT CONTROL STATEMENT - CASE STUDY OF THE CZECH REPUBLIC
}

\author{
Lukáš Moravec ${ }^{1}$, Jana Hinke1, Monika Borsiczká1 \\ ${ }^{1}$ Department of Trade and Finance, Faculty of Economics and Management, Czech University of Life Sciences
}

Link to this article: https://doi.org/10.11118/actaun.2021.034

Received: 19. 7. 2020, Accepted: 10. 5. 2021

To cite this article: MORAVEC LUKÁŠ, HINKE JANA, BORSICZKÁ MONIKA. 2021. Fiscal Effect of VAT Control Statement - Case Study of the Czech Republic. Acta Universitatis Agriculturae et Silviculturae Mendelianae Brunensis, 69(3): 365-377.

\begin{abstract}
This article first aims to identify the final fiscal amount of the VAT control statement in the selected region and then to transform it to determine the theoretical fiscal amount in the entire Czech Republic. The second goal is to identify a possible impact of VAT control statements on tax evasion. For this purpose, the following tools have been used: calls for submission of control statements, reasons to initiate inspection arising from matching the control statements, tax audits, and the process to remove tax doubts. Using the foregoing tools, the theoretical fiscal revenue is quantified and then compared with the VAT gap from 2015 to 2016. The VAT gap is measured by adjusting the gross domestic product; the data from the national accounts database published by the Czech Statistical Office are used as the basic data source. The authors have arrived at the conclusion that once the financial administration implemented the selected tools for total tax collection, then right after implementing the VAT control statements in 2016 the VAT gap slightly decreased in comparison with the previous year (and in proportion to year-on-year comparison of GDP), which resulted in the increase in the overall VAT collection.
\end{abstract}

Keywords: value added tax, control statement, fiscal effect, payer, tax evasion

\section{INTRODUCTION}

The domestic legislation dealing with tax issues has been fundamentally amended in recent years, which means that it is automatically subject to a certain interest in the context of the Czech national thinking, namely both negative reactions, i.e., criticising the newly introduced measures, and positive reactions, for example, fully appreciating the relevant "innovation" as a global, progressively oriented asset.

In the first phase, the implementation of individual provisions (specifically the institute of the VAT control statement and the implementation of electronic records of sales) dating back to 2016, is associated with multilateral costs of the financial administration, taxable entities and involved third parties. The secondary, explicitly incurred expenditures are irrelevant to monitor without an appropriate time lag.
The fiscal benefit of the aforementioned measures, used to eliminate tax evasion, initially predicted increasing the state budget by CZK 5-10 billion per year in the case of VAT control statements (Ministry of Finance of the CR, 2015), and in the case of electronic records of sales by CZK 5.7 billion for the retail sector, except for motor vehicles and the hospitality sector (Parliament of the CR, 2014).

The introduction of (not only) the above-mentioned mechanisms has aimed to prevent losses of value added tax as much as possible, and thus to achieve a decrease in the estimated gap. Both the existing and newly introduced tools, which are available either to tax administrators themselves or to them in cooperation with prosecuting authorities, are the means for eliminating the value added tax evasion. This paper focuses just on the issues of preventing tax evasion by introducing the institute of VAT statement. 


\section{Theoretical Background}

Value added tax can be regarded as a tax acting equally towards all the parties, or more precisely, it is a competition neutral tax in the market environment (Stř́lková and Široký, 2015). Kristofik et al. (2017) mention both the advantages and disadvantages resulting from the value added tax. They state its neutrality, applicability in the context of intracommunity payments, transparency, benefit for the state budget (the VAT collection in the Czech Republic has represented approximately half of the total collection of all taxes in the long run) and its resistance to tax evasion as its positives. It is necessary to note that the efficiency of its positives has been changing over the individual years because of implementing new instruments that are able to better use the mechanism of value added tax. Its drawbacks can be seen in high requirements placed on the necessary administration, not only in its implementation in a certain country but also in the follow-up application (in the sense of fulfilling tax duties by taxable entities and checking compliance by the tax administration).

Value added tax also influences the market environment, where the percentage rate is reflected in the price of goods and services and possible changes in this algorithm have impact not only on the inflation rate but also on the market behaviour of economic entities. Zimmermanová et al. (2015) or Široký and Stř́lková (2014) note that the growth of the VAT percentage rate often causes a follow-up growth of market prices in real life; paradoxically, if the VAT rate decreases, there is no price fall in the concerned goods (authors' note: for example, in the Czech Republic there was a drop in the VAT rate of newspapers and magazines from 15\% to 10\% starting in March 2017).

A lot of authors (e.g., Moravec et al., 2018; Zidkova, 2014 or Kostakova and Zidkova, 2015) deal with the right calculation of tax evasion in VAT, that is situations when the tax liability is intentionally lowered (or applying excessive deductions) either in a legal way by using inaccuracies in the valid legal regulations or in an illegal way by committing criminal acts and causing high damage to VAT collection. The inspecting and other mechanisms of tax administrators are used to prevent illegal tax evasion. In this respect, high flexibility of tax administrator is necessary when introducing the new institutes and implementing the current ones (Semerad and Bartunkova, 2016).

To make the inspecting mechanisms within the VAT administration more efficient, the tax administration should use the institute of VAT control statement, which aims to reveal carousel frauds, also to eliminate the risk of tax avoidance and evasion by common taxpayers and to detect faults (errors) caused by, for example, carelessness when processing the accounting agenda or ignorance of law, and thus to prevent possible unintentional tax evasions (Volkova and Tomanova,
2016). Examples of such frequent unintentional mistakes in accounting are as follows: discrepancies in accounting for advance payments, mistakes in registration numbers of tax documents, mistakes in tax identification numbers and in data of making the tax returns and so on (Dušek, 2016). Other tools of the financial administration that help to collect the tax include local investigation, electronic records of sales, summary VAT statements, the local reverse charge regime, the scope of authority of customs offices, the process to remove tax doubts, the tax audit, the institute of liability, securing tax orders, "Tax Cobra" (a special police team) and the institute of unreliable taxpayers/taxable entities. All of those aim to determine and collect the tax in such a way so that there is no tax avoidance and evasion, and the VAT gap is minimized, i.e., the difference between the theoretically and really collected tax (General Financial Directorate, 2018). The gap growth means a reduction in state budget revenue, which is becoming an even more serious problem, especially at the time of increased expenditures in the current situation (COVID-19 pandemic). Based on the national data and Eurostat data, Hybka and Malgorzata (2018) calculated the most important VAT performance indicators of Germany and Poland and evaluated the factors reducing the VAT efficiency in these countries in comparison with other member states of the European Union. These authors rank Poland and the Czech Republic among the member states with a higher tax gap than the EU average is.

The issues of reducing the VAT gap are researched all over the world where solutions for the single economy are being searched for, which implies the importance of these issues. For example, in their publication Canikalp et al. (2016) estimated and evaluated the VAT gap in Turkey for the period of 1993-2014 by employing the top-down method. Indirect methods (also referred to as macroeconomic or top down) use national accounts data for their estimates. These methods were used, for example, by Reckon (Reckon, 2009) in the study measuring the VAT gap for individual EU countries, the Institute of Financial Policy (IFP, 2012), the CASE study: "Center for Social and Economic Research” (CASE, 2013, 2014, 2015) and Stavjaňová (Stavjaňová, 2014). Indirect methods first calculate the theoretical VAT liability and then the actually collected tax (based on the accrual principle) is deducted from it. There are two basic methods to determine the theoretical VAT liability: the first one deducts from the GDP items that are not subject to VAT and the second one is based on the supply and use tables. As all the above authors and companies use this method, it will be used in this article as well.

By analyzing Web of Science and Scopus citation databases, the authors of this article have found that only several articles about VAT control statements have been published by the domestic 
authors, which ensues from the fact that this tool was implemented in the Czech Republic in 2016. The one by Semerad et al. (2016) deals with problematic aspects related to drawing up and submitting VAT inspection statements to taxpayers mostly to sanction threats and analysis of additional administrative and financial costs. The other paper by Semerad and Bartunkova (2016) tries to quantify the possible impact on taxable entities belonging to the category of small and middle-sized enterprises. Krzikallova and Tosenovsky (2020) use the regression methods for the time series official data on copper exports from the Czech Republic to Slovakia, along with the relevant statistical tests to detect the potential significance of new legislative instruments, i.e., the VAT control statement and the reverse charge mechanism.

Arltova et al. (2020), who evaluate the effectiveness of measures against VAT evasion as introduced in the Czech Republic, are closest to this article. Their analysis of the quarterly time series of VAT revenue from 1999 to 2016 has shown that of all the anti-fraud measures, the tightening of rules for unreliable taxpayers introduced at the beginning of 2013 proves to be the most effective in models. "A significant, positive effect has also been identified with adopting the reverse charge mechanism on scrap and emission allowances, as well as with the implementation of the VAT control statement - in both cases the quarterly effect exceeds CZK 2 billion”.

From the above mentioned, it can be deduced that there has not been yet published any academic output which would have similar goals and methods that the authors of this study have set.

\section{MATERIALS AND METHODS}

This study first aims to identify the final fiscal amount of the VAT control statement in the selected region and then to transform it to determine the theoretical fiscal amount in the entire Czech Republic.

To achieve this goal, first the sample selected from the fifteen financial authorities of the Czech Republic is described, i.e., the Tax Office for the Olomouc Region, in terms of the development of the VAT tax returns number and the amount of tax collected. The amount of the tax change is determined from the data obtained from the internal database of the Tax Office for the Olomouc Region and it is influenced by the VAT control statement and other tools which the financial administration uses to fight against the tax evasion. The amount is subsequently transformed using the two methods of unit conversation to calculate the theoretical fiscal revenue of the entire Czech Republic - firstly, it is converted into the registered active VAT payers and, secondly, into the number of issued calls for submitting the VAT control statement and reasons to initiate inspection arising from matching the control statements.

The Tax Office for the Olomouc Region is one of the fifteen financial authorities and the only one for which the authors obtained data for the selected methodology. Primarily, this financial authority has been selected because of the data availability. The detailed analysis of the selected financial authority presented by the authors is the only one that exists and due to the absence of data for the whole Czech Republic the authors had to accept the practice that the ratio of individual factors is similar to the selected region aggregated for the whole Czech Republic, or more precisely that the data for the selected financial authority can be extrapolated on the whole Czech Republic in order to estimate the total revenue from the VAT control statement. The authors do not use the data from the Tax Office for the Olomouc Region to generalize fundamental conclusions, but they use them to recalculate the data for the entire Czech Republic in a model way using the financial ratios. The assumption of the informative value of the results based on the data from the Olomouc Region is confirmed by the finding that the authors' obtained recalculated values for the Czech Republic range within the published national estimates of the Ministry of Finance, which quotes the interval of CZK 10-18 billion depending on the methodology (MF, 2017).

The second goal of the paper is to identify the possible share of VAT control statements in the tax evasion. For this purpose, the following tools have been used: calls for submission of VAT control statements, reasons to initiate inspection arising from matching the control statements, tax audits, and the process to remove tax doubts. Using the foregoing tools, the theoretical fiscal revenue is quantified and then compared with the VAT gap from 2015 to 2016. The VAT gap is measured by adjusting the gross domestic product in a way that the data from the national accounts database published by the Czech Statistical Office are used as the basic data source. The authors have adopted the specific calculation procedure from the method stated in the publications of Moravec et al. (2018) or Zidkova (2014). The reason for that is to exactly determine the national accounts data used that are the subject of the calculation. However, the exact replication of calculating the VAT gap is not the content of this paper. The calculations, and graphical and tabular representation of outcomes are processed in Excel.

The authors have arrived at the conclusion that once the financial administration implemented the selected tools for total tax collection, then right after implementing the VAT control statements in 2016 the VAT gap slightly decreased in comparison with the previous year (and in proportion to year-on-year comparison of GDP), which resulted in the increase in the overall VAT collection.

The following hypotheses have been defined from the above-mentioned goals. They should be either confirmed or rejected by the analysis described in this paper. 
Hypothesis 1: Based on the available data, the total fiscal revenue from the VAT control statements of the Olomouc Region can be quantified and then recalculated for the entire country both using the variable of the number of VAT payers, and the variable of the number of generated calls to complete or confirm data and reasons to initiate inspection arising from matching the control statements. The amounts will not differ by more than CZK 100 million.

Hypothesis 2: It can be stated that the tools, such as calls for changing, completing or confirming the VAT control statement, reasons to initiate inspection arising from matching the control statements, and the process to remove tax doubts, have contributed to the nationwide fiscal revenue from the value added tax amounting to billions of Czech crowns, which means that they account for several percentage units in the total estimated VAT gap for 2016. The study is based on the available data starting from 2012.

\section{RESULTS}

\section{Fiscal Revenue from the VAT Control Statements in the Olomouc Region}

\section{Characteristics of the Region in Terms of the Value Added Tax}

The total of 25,221 taxpayers registered in the VAT payer database of the Tax Office for the Olomouc Region were regarded as active ones (they had a valid registration for value added tax, they submitted tax returns) at the end of 2016. The Tax Office for the Olomouc Region accounted for five percent in the total number of taxpayers within the Czech Republic in 2016 (Financial Administration, 2018a).

The development of the number of taxpayers in the mentioned region shows a slightly decreasing trend. The data have been observed since 2013 (in contrast to other data which the authors have been processing since 2012) because of the change in the tax administration structure. The reorganization valid since 1 January 2013, when Act No. 456/2011 Coll. on the Financial Administration of the Czech Republic came into effect, has impacted on the regional structure and hierarchy of individual bodies, i.e., also on the data collection used to process outputs for relevant regions. Since 2013 the total number of value-added taxpayers within the Tax Office for the Olomouc Region has been slightly decreasing - in 2014 by $0.10 \%$, in 2015 by $0.51 \%$ and in 2016 by $1.16 \%$. The decrease in the number of value-added taxpayers can be seen only in the category of small businessmen - natural persons. On the contrary, in the case of legal persons, municipalities and regions, there is a noticeable increase in the number of entities registered for value added tax. Despite the fall in the number of value-added taxpayers there is a rise in unreliable taxpayers. The reason for that is the fact that this institute was introduced in 2013, but it was not implemented until 2014 because of amending the Information of the General Financial Directorate relating to the application of the status of unreliable payer (the Financial Administration, 2014). Given the facts mentioned above, it is logical that the number of unreliable payers increased, especially in 2015, when the tax administrator already had suitable tools in the form of legal regulations to issue decisions in this matter. The data on the number of submitted tax returns, the tax amount from these returns, the total assessed tax liability, and tax collection are available to the public in the tax statistics processed by the responsible department of the General Financial Directorate - see Tab. I.

Although the number of VAT payers in the Olomouc Region shows a year-on-year decrease, both the reported and collected tax has a rising trend. The average percentage increase in the VAT collection from 2012 to 2015 is $9.01 \%$. As a result of this fact and in view of the implementation of the VAT control statement mechanism, which should increase the VAT collection (a reduction in tax evasion), it can be assumed that in 2016 it will be increasing compared to previous years.

\section{Calls for Changing, Completing or Confirming the VAT Control Statement}

In connection with the introduction of the institute of VAT control statement, the authors looked into the data on the submitted follow-up VAT statements, on the numbers of tax returns in response to calls for confirming the completeness and correctness of VAT control statements from the internal database of the Tax Office for the Olomouc Region to find out the impact of them on tax changes.

I: Selected data from the value added tax returns

\begin{tabular}{lcccc}
\hline \multicolumn{1}{c}{ VAT - the Olomouc Region } & 2012 & 2013 & 2014 & 2015 \\
\hline Number of submitted tax returns & 144,413 & 147,072 & 159,679 & 167,711 \\
Declared tax from tax returns* & $4,718,071$ & $4,084,587$ & $4,776,473$ & $5,395,643$ \\
The total assessed tax liability* & $4,246,901$ & $4,397,455$ & $4,220,201$ & $5,568,840$ \\
Revenue collection * & $4,083,221$ & $4,543,839$ & $4,429,462$ & $5,594,784$ \\
\hline
\end{tabular}

* in thousands of CZK

Source: own processing according to the Financial Administration, 2018b 
Based on the total number of 6,021 calls form confirming the completeness and correctness of the latest submitted VAT control statement, 373 tax returns were filed, i.e., there was a tax change in $6.19 \%$ of issued calls. As a result of issued calls for confirming or completing data, there was a change in the tax liability reported by taxable entities payers of VAT - in the total amount of CZK 10,336,017 for the tax period from January to December 2016 (as of 30 May 2017). The recalculations of the fiscal revenue are presented in Tab. II.

In the case of recalculating the fiscal revenue per one tax return filed after the call, the tax change would therefore amount to CZK 27,619. The theoretical fiscal revenue from the data available above would amount of CZK 1,717 per one call for changing, completing or confirming the data.

When classifying according to the entity type, the calls for changing, completing, or confirming the data were delivered to:

- Natural persons: 1,705 (28\%).

- Legal persons: 4,271 (71\%).

- Groups: 45 (1\%).

The sectors in which the tax change is most frequently recorded are (the Tax Office for the Olomouc Region, 2017):

- Wholesale, except for motor vehicles - tax change: CZK 2,030,258.

- Real estate activities - tax change: CZK 934,977.

- Retail business, except for motor vehicles - tax change: CZK 776,011.

- Other professional, scientific, and technical activities - tax change: CZK 740,720.

Areas where the tax change is most frequently recorded (Financial Authority for Olomouc).

\section{Sanctions Related to the VAT Control Statement}

In the event that the taxable entity responds to the call for after the deadline or the delivered call for has remained without any response, the tax administrator proceeds to the sanction system of fines for the non-filed VAT control statement. The statistical data for 2016 on the issued fines for calls are shown in the following table - Tab. II.

As to the table shown above, it is necessary to add that most fine types above were imposed (and subsequently issued after the Act became effective) retroactively at the beginning of 2017. The reason for the time lag between issuing the payment orders and the commencement of imposing fines was the publishing of the Constitutional Court ruling of 19 December 2016, which concerns the obligation of the tax administrator to send call for VAT control statements electronically. Based on this ruling, the methodical instructions related to the sending of calls for VAT control statements via e-mail have been altered. The above data do not have to consider the fact that the prescribed sentence was later repealed as a result of tax remission. Starting from 2017, therefore, a rapid increase in the number of fines imposed can be statistically expected.

According to the published information of the General Financial Directorate (2017) the most frequently imposed fines (both in the number and in the amount) were those for not submitting the VAT control statement, when the entity had not responded to the call for VAT control statement of the tax administrator. The authors think that majority of these fines concerns taxpayers who are not possible to be contacted or communication with them is exceedingly difficult. This implies that the imposed fine will not be paid or enforced and the desired result, nor the educative nature of the imposed fines will be achieved.

The percentages of the VAT control statement can be expressed as follows:

- Calls for submitting VAT control statement account for $12 \%$.

- No responses to calls for changing, completing, or confirming the VAT control statement within the deadline account for $10 \%$.

- No responses to calls for submitting VAT control statement account for $78 \%$.

\section{Reasons to Initiate Inspection Arising from Matching the Control Statements}

As of 30 May 2017, the total of 4,044 audits were recorded on behalf of the Tax Office for the Olomouc Region for the tax period from January to December 2016, related to the reasons for initiating inspection arising from matching the VAT control statements. The Tab. III presents the unit recalculation.

The total fiscal revenue from the closed reasons amounts to CZK 17,396,120. The tax change per one investigated reason can thus be determined in the amount of CZK 4,302.

II: Fines for VAT control statements in 2016

\begin{tabular}{lccc}
\hline \multicolumn{1}{c}{ Type of fines } & Amount of fine (CZK) & Total number of fines & To be fined (CZK) \\
\hline Call for submitting VAT control statement & 10,000 & 208 & $2,080,000$ \\
$\begin{array}{l}\text { No response to call for changing, } \\
\text { completing, or confirming VAT CS }\end{array}$ & 30,000 & 185 & $5,550,000$ \\
No response to call for submitting VAT CS & 50,000 & 1,383 & $69,150,000$ \\
\hline
\end{tabular}

Source: own processing according to the General Financial Directorate, 2017 


\section{Total Fiscal Revenue from the VAT Control Statements for the Olomouc Region}

In total, 10,065 cases concerning discrepancies, which had to be dealt with by tax administrators, were reported in the VAT control statements and they were sent to individual territorial offices performing tax administration within the competence of the superior authority, i.e., the Tax Office for the Olomouc Region (2017). Fig. 1 shows the number of reasons investigated, the number of calls issued and a summary of their fiscal effect.

Therefore, the above cases had an overall effect on the increase in the tax liability to the Tax Office for the Olomouc Region by CZK 27,732,137.

\section{Theoretical Fiscal Revenue for the Entire Country}

Through the data published on the official bulletin board of the General Finance Directorate (GFD, 2017), the information on the number of calls handed over to the individual territorial offices (but not delivered to taxable entities) and on the number of inspections made due to discrepancies in pairing the VAT control statements was obtained. This information was issued on 24 February 2017, but we may assume that the numbers were obtained as of 31 December 2016:

Given the fact that the authors do not have any data about the tax changes for other regions of the Czech Republic, two indirect methods to calculate the total possible fiscal revenue for the entire Czech Republic have been selected, namely recalculation to the registered active VAT payers and recalculation to the issued calls for VAT control statements and reasons to initiate inspection due to discrepancies in pairing the VAT control statements.

\section{A) Recalculation to Taxpayers}

The tax change calculated in this way consists in determining the variables, which are the number of VAT payers for the Tax Office for the Olomouc Region and for the entire Czech Republic and finding out the theoretical tax change for the entire Czech Republic on the basis of tax change data for Tax Office for the Olomouc Region, with the number of taxpayers being set as the key factor for the calculation.

III: Recalculation of the tax change per one reason for initiating inspection

\begin{tabular}{lcc}
\hline \multicolumn{1}{c}{ Reasons in 2016 } & $\begin{array}{c}\text { Total for Tax Office } \\
\text { for the Olomouc Region }\end{array}$ & Unit recalculation \\
\hline Number of reasons & 4,044 & 1 \\
Tax change (in CZK) & $17,396,120$ & 4,302 \\
\hline
\end{tabular}

Source: own processing, 2018 according to data of the Tax Office for the Olomouc Region, 2017

$17,396,120$

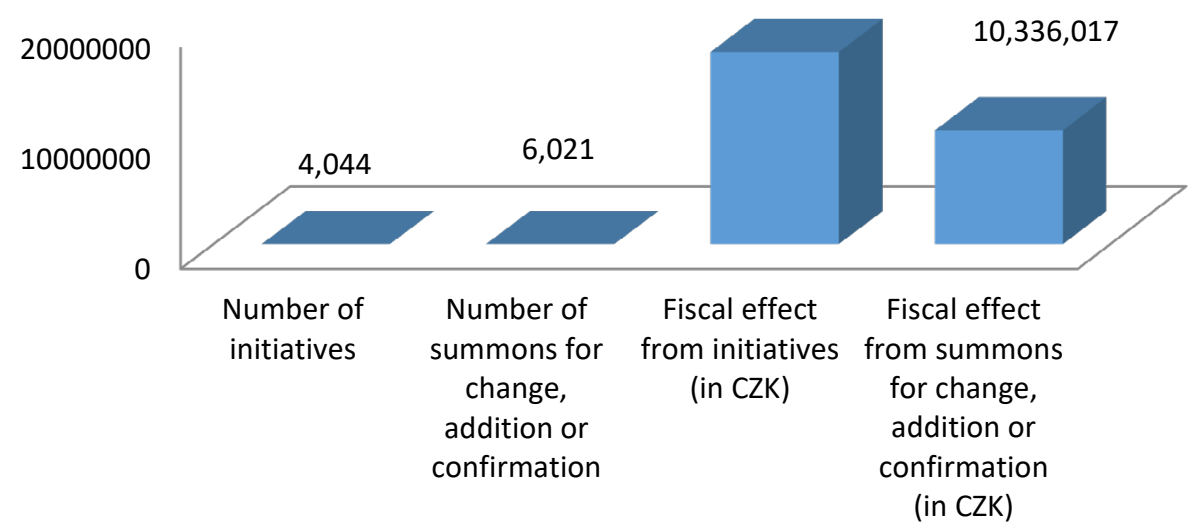

1: The total number of reasons to initiate inspection and calls in 2016 and the total fiscal effect from reasons to initiate inspection and calls in 2016

Source: own processing, 2018 according to the Tax Office for the Olomouc Region, 2017

IV: Number of calls for VAT control statement and reasons to initiate inspection for the Czech Republic in 2016 (in pcs)

Instrument

Call for changing, completing, or confirming the VAT control statement

Reasons to initiate inspection
Number for the entire country

124,808

55,700

Source: own processing, 2018, according to the Tax Office for the Olomouc Region, 2017 
When defining the number of taxpayers as the main determinant, the total tax change (the increase in the value added tax liability for 2016 resulting from the basic tools of the financial administration in detecting discrepancies when implementing the VAT control statement as the obligation imposed by law to taxpayers) would amount to CZK 553,240,794.

\section{B) Recalculation to Issued Calls for VAT Control Statements and Reasons to Initiate Inspection}

The data on the number of generated calls for completing or confirming data and reasons to initiate inspection due to discrepancies in pairing the VAT control statements for the entire Czech Republic probably provide more accurate calculation. The number of cases for the Tax Office for the Olomouc Region is compared with the number of cases for the entire Czech Republic and, as a follow-up, the unit tax change determined from the data for the selected region is recalculated to the total number of generated cases.

When considering the number of generated cases, i.e., the calls for VAT statement control and reasons to initiate inspection, to be the main factor for calculating the tax change for the entire Czech Republic, the resulting value of the fiscal revenue in the sense of prescribed tax liability amounts to CZK 453,916,736. The comparison of results for individual outputs is shown below in Tab. VII.

Nevertheless, in both calculations it is an estimate based on the data provided for a single region. There is no doubt that data for other tax offices differ. The data from the tax statistics published on the website of the Financial Administration would definitely provide more accurate result, but those were not available when this document was processed. The calculation may be also influenced by the fact whether the information on the number of calls for the entire Czech Republic includes data from the Specialized Financial Authority, because the information from the General Financial Directorate ref. No. 19/2017 says that: "within the comparison of VAT control statements (hereinafter referred to as "CS") and identifying discrepancies in the CS data, inputs (documents) have been generated at the central level for the local tax offices...”(GFD, 2017). This results in the ambiguity of the statement as to whether the Specialized Tax Office is also considered a territorial office in the matter of these calls for VAT control statement. In any case, Tab. VIII confirms Hypothesis 1 defined in the Materials and Methods.

Not only the Act on VAT, by which the mechanism of VAT control statements has been implemented into the tax system, but also the tax rules allow the tax administrator to apply such tools that help to correctly determine the tax within the tax procedure. If we leave aside the tools such as "Searching activity" and "Local investigation", whose use is a necessary part of everyday work of a tax administrator when cooperating with a taxable entity, the subject of the following processing is "Tax audit" and "Process to remove tax doubts". Within these processes other steps leading to finding out facts that are crucial for the right tax

$\mathrm{V}$ : Recalculation of calls for VAT control statement and reasons to initiate inspection to the CR (according to the number of taxpayers, in $C Z K$ )

\begin{tabular}{cccc}
\hline Location & Number of taxpayers & $\begin{array}{c}\text { Tax change based on calls } \\
\text { (in CZK) }\end{array}$ & $\begin{array}{c}\text { Tax change based on reasons } \\
\text { (in CZK) }\end{array}$ \\
\hline The Olomouc Region & 25,221 & $10,336,017$ & $17,396,120$ \\
The Czech Republic & 503,145 & $206,197,822$ & $347,042,972$ \\
\hline
\end{tabular}

Source: own processing, 2018, according to the Tax Office for the Olomouc Region, 2017

VI: Recalculation of calls for VAT control statements and reasons to initiate inspection for the entire Czech Republic (according to number of calls and reasons)

\begin{tabular}{|c|c|c|c|c|}
\hline Location & Number of calls & $\begin{array}{l}\text { Tax change based on calls } \\
\text { (in CZK) }\end{array}$ & Number of reasons & $\begin{array}{l}\text { Tax change based on reasons } \\
\text { (in CZK) }\end{array}$ \\
\hline The Olomouc Region & 6,021 & $10,336,017$ & 4,044 & $17,396,120$ \\
\hline The Czech Republic & 124,808 & $214,295,336$ & 55,700 & $239,621,400$ \\
\hline
\end{tabular}

Source: own processing according to the Tax Office for the Olomouc Region, 2017

VII: Recalculation of calls for VAT control statement and reasons to initiate inspection for the Czech Republic (according to the number of calls and reasons, in CZK)

\begin{tabular}{lccc}
\hline \multicolumn{1}{c}{ Comparison of results of CR } & Calls & Reasons & Total \\
\hline Tax change - number of payers & $206,197,822$ & $347,042,972$ & $553,240,794$ \\
Tax change - number of cases & $214,295,336$ & $239,621,400$ & $453,916,736$ \\
Difference & $8,097,514$ & $107,421,572$ & $99,324,058$ \\
\hline
\end{tabular}

Source: own processing, 2020 
determination can be launched, or more precisely they can lead to elimination of tax evasions and to achieving higher tax revenue (different forms of international cooperation), with using the common means stating one-sided information about details of fulfilling (the application for the possibility of operational responses to realized local and international transactions - the type of reverse charge regime, summary report, etc.).

\section{Tax Audit}

The number of audits and of additionally assessed value added taxes are shown in the following table - Tab. VIII. The decreasing trend of the number of finished tax audits can be read in the data.

In connection with the implementation of VAT control statement, it can be assumed that in 2016, when there was a decrease in the number of finished tax audits by $18 \%$, this situation occurred due to the start of a number of tax audits as a result of investigation of discrepancies of different nature and carousel frauds detected thanks to the introduction of the duty to file VAT control statements. This assumption is also supported by the table below, where it is clear that the lower number of tax audits had no significant influence on the additional tax assessed. When comparing 2015 and 2016, there was a year-on-year decrease in the amount of additionally assessed tax by 9\%; however, in the case of unit recalculation of the additionally assessed tax per one finished tax audit, the revenue is the highest for all the observed periods (see Tab. IX).

VIII: Number of tax audits and of additionally assessed value added taxes in the $C R$

\begin{tabular}{ccc}
\hline Year & Number of audits & $\begin{array}{c}\text { Additionally assessed tax } \\
\text { (in thousands of CZK) }\end{array}$ \\
\hline 2012 & 13,466 & $6,830,573$ \\
2013 & 10,228 & $7,033,203$ \\
2014 & 11,565 & $8,259,054$ \\
2015 & 10,130 & $13,660,791$ \\
2016 & 8,351 & $12,454,914$ \\
\hline
\end{tabular}

Source: own processing according to the Financial Administration, 2018c

\section{Process to Remove Doubts (Hereinafter Referred to as PRD)}

The implementation of VAT control statements could have positively influenced the processing of call for removing doubts itself addressed to taxable entities. The benefit may consist in the fact that by submitting the VAT control statement the taxpayer provides the tax administrator with the details of transactions and the tax administrator can precisely define the payments for which the taxpayer should produce documents to prove the required data and thus to specify ambiguities in accordance with the duty in the relevant process to remove doubts.

Also, in the number of processes to remove doubts, which were completed with the difference in tax, a declining trend by almost $25 \%$ can be observed in 2016 compared to 2015. Compared to tax audits, there is no assumption of a significant potential difference between processes initiated and unfinished, namely due to the time limit by which the tax administrator is bound in the ongoing process to remove doubts and by the related possible interest on the tax deduction which would belong to the taxpayer.

In 2016, there was not only the lowest yearon-year decrease in the revenue for the selected periods (by 54\% compared to the previous year), but also the lowest revenue recalculated to one process to remove doubts, based on which the tax was determined differently from the tax originally assessed. There was a total decrease not only in the lower value of tax revenue, but also in the excessive deduction.

The reduction in the number of processes to remove doubts in 2016 could have theoretically been influenced by the implementation of VAT control statements, in the sense of eliminating some discrepancies caused by taxpayers when recording the accounting cases (eliminating mistakes due to higher consistency of accountants "respecting" the newly introduced control statement, discrepancy notices in the form of calls for changing, completing, or confirming data), and also the possible, initial caution of taxable entities when claiming tax deductions, which could have shown signs of tax evasion.

IX: Year-on-year comparison of tax audits

\begin{tabular}{cccc}
\hline Year & $\begin{array}{c}\text { Year-on-year comparison } \\
\text { of the number } \\
\text { (in \%) }\end{array}$ & $\begin{array}{c}\text { Year-on-year comparison } \\
\text { of the revenue } \\
\text { (in \%) }\end{array}$ & $\begin{array}{c}\text { Revenue recalculated } \\
\text { per one tax audit } \\
\text { (in thousands of CZK) }\end{array}$ \\
\hline 2012 & - & - & 507 \\
2013 & 24 & 3 & 688 \\
2014 & 13 & 17 & 714 \\
2015 & 12 & 65 & 1,349 \\
2016 & 18 & 9 & 1,491 \\
\hline
\end{tabular}

Source: own processing, 2020 
$\mathrm{X}$ : Number of finished PRD concerning VAT with the assessed difference from the tax originally assessed and the total revenue based on PRD concerning VAT

\begin{tabular}{ccc}
\hline Year & $\begin{array}{c}\text { Number } \\
\text { of finished PRD }\end{array}$ & $\begin{array}{c}\text { Total revenue based on PRD } \\
\text { (in thousands of CZK) }\end{array}$ \\
\hline 2012 & 7,767 & $9,234,601$ \\
2013 & 5,484 & $4,590,515$ \\
2014 & 8,312 & $6,282,288$ \\
2015 & 10,011 & $10,564,998$ \\
2016 & 7,552 & $4,872,856$ \\
\hline
\end{tabular}

Source: own processing according to the Financial Administration, 2018c

Reasons to initiate inspection arising from pairing of VAT control statements can also be a tool to detect wrongfully reported payments in time. In response to details of such a case, the following steps, such as rectifications by taxpayers themselves, starting the process to remove doubts or starting tax audits and others, always with respect to valid methodical instructions, can follow.

Based on the selected tools available to the financial administration, the authors have identified the following fiscal revenue from VAT - see Tab. XII.

However, the total revenue when using the selected tools is lower in 2016 in comparison with the previous year. The reason for that is the overall decrease in the revenue based on tax audits and processes to remove doubts. Although the new institute of VAT control statements has been implemented, this tool does not account for high in the total fiscal revenue (in total only 2.56\%).

\section{The Relation Between the VAT Gap and Defined Instruments}

The authors have also calculated the theoretical tax liability by adjusting the GDP according to the methodology that was described in detail in the publication of Moravec et al. (2018) and Zidkova (2014) and have compared it with the actually collected VAT in the same years - see Tab. XIII.

XI: Year-on-year comparison of processes to remove doubts

\begin{tabular}{|c|c|c|c|c|c|}
\hline Year & $\begin{array}{c}\text { Year-on-year comparison } \\
\text { of the number } \\
\text { (in } \%)\end{array}$ & \multicolumn{2}{|l|}{$\begin{array}{c}\text { Year-on-year comparison } \\
\text { of the revenue } \\
\text { (in \%) }\end{array}$} & \multicolumn{2}{|l|}{$\begin{array}{l}\text { Revenue recalculated } \\
\text { to } 1 \text { finished PRD } \\
\text { (in thousands of CZK) }\end{array}$} \\
\hline 2012 & - & \multicolumn{2}{|l|}{-} & \multicolumn{2}{|l|}{576} \\
\hline 2013 & -29 & \multicolumn{2}{|l|}{-50} & \multicolumn{2}{|l|}{376} \\
\hline 2014 & 52 & \multicolumn{2}{|l|}{37} & \multicolumn{2}{|l|}{380} \\
\hline 2015 & 20 & \multicolumn{2}{|l|}{68} & \multicolumn{2}{|l|}{598} \\
\hline 2016 & -25 & \multicolumn{2}{|l|}{-54} & \multicolumn{2}{|l|}{361} \\
\hline \multicolumn{6}{|c|}{ Source: own processing, 2020} \\
\hline & Tool & $\begin{array}{l}2015 \\
\text { (in thousands of CZK) }\end{array}$ & $\begin{array}{c}2015 \\
\text { (in \%) }\end{array}$ & $\begin{array}{l}2016 \\
\text { (in thousands of CZK) }\end{array}$ & $\begin{array}{l}2016 \\
\text { (in \%) }\end{array}$ \\
\hline \multicolumn{2}{|c|}{ Calls for VAT control statements } & 0 & 0 & 214,295 & 1.21 \\
\hline \multicolumn{2}{|c|}{ Reasons to initiate inspections of VAT control statements } & ents & 0 & 239,621 & 1.35 \\
\hline \multicolumn{2}{|c|}{ Calls and reasons to initiate inspections in tot } & 0 & 0 & 453,916 & 2.56 \\
\hline \multicolumn{2}{|l|}{ Tax audits } & $13,660,791$ & 56.39 & $12,454,914$ & 70.04 \\
\hline \multicolumn{2}{|c|}{ Process to remove doubts } & $10,564,998$ & 43.61 & $4,872,856$ & 27.40 \\
\hline \multicolumn{2}{|c|}{ Tools in total } & $24,225,789$ & 100 & $17,781,686$ & 100 \\
\hline
\end{tabular}

Source: own processing, 2020

XIII: Theoretical tax liability, actual VAT collection and their comparison

\begin{tabular}{lcc}
\hline \multicolumn{1}{c}{ Aspect/Year } & 2015 & 2016 \\
\hline Theoretical tax liability (in mil. of CZK) & 437,344 & 443,568 \\
Actual collection (in mil. of CZK) & 331,836 & 349,460 \\
VAT gap (in mil. of CZK) & 105,508 & 94,108 \\
VAT gap (in \%) & 24.12 & 21.22 \\
\hline
\end{tabular}

Source: own processing, 2020 
XIV: Share of the selected tools in the actual collection (in millions of CZK)

\begin{tabular}{lcccc}
\multicolumn{1}{c}{ Type of share/Year } & $\begin{array}{c}2015 \\
\text { (in mil. of CZK) }\end{array}$ & $\begin{array}{c}2015 \\
\text { (in \%) }\end{array}$ & $\begin{array}{c}2016 \\
\text { (in mil. of CZK) }\end{array}$ & $\begin{array}{c}2016 \\
\text { (in \%) }\end{array}$ \\
\hline Share of VAT control statements in the actual collection & 0 & 0 & 454 & 0.13 \\
Share of tax audits and PRD in the actual collection & 24,226 & 7.3 & 17,328 & 4.96 \\
Share of the selected tools in the actual collection in total & 24,226 & 7.3 & 17,782 & 5.09 \\
\hline
\end{tabular}

Source: own processing, 2020

XV: Actual VAT collection without fiscal benefits of the financial administration and the VAT gap without fiscal benefits

\begin{tabular}{lcc}
\hline \multicolumn{1}{c}{ Aspect/Year } & 2015 & 2016 \\
\hline Actual collection without fiscal benefits (in mil. of CZK) & 307,610 & 331,678 \\
VAT gap without financial administration interference (in mil. of CZK) & 129,734 & 111,890 \\
VAT gap without financial administration interference (in \%) & 29.66 & 25.22 \\
\hline
\end{tabular}

Source: own processing, 2020

Provided that the selected tools, which were used to realize the fiscal revenue, were part of the actual collection of value added tax, the following can be deduced.

The actual VAT collection without showing the benefits of the mentioned tools can be calculated from the above facts and considering this, we can determine the gap in VAT, which does not take into account the fiscal revenue of individual tools. The total decrease in the VAT gap can be observed if the input data on the actual incomes are the incomes without a change in tax based on the calls for VAT control statements, reasons to initiate inspections, without additionally assessed tax from tax audits and without revenue from processes to remove doubts.

Based on the data above it is possible to identify that just by the influence of selected tools of the financial administration there was a decrease in the tax gap

- by $5.54 \%$ in 2015 (ranging from 29.66\% to $24.12 \%$, i.e., ranging from CZK 129,734 mil. to CZK 105,508 mil.) and

- by $4.00 \%$ in 2016 (ranging from $25.22 \%$ to $21.22 \%$, i.e., ranging from CZK 111,890 mil. to CZK 94,108 mil.).

Although the total percentage comparison shows a higher figure for 2015, there was a decrease in the VAT gap in 2016 in total. This fact is proved by comparing the tax gap estimate in the stated years:

1. for the version without the use of the financial administration tools, there was a reduction in the VAT gap by $4.44 \%$ (the tax gap decreased from $29.66 \%$ to $25.22 \%$, i.e., from CZK 129,734 mil. to CZK 111,890 mil.),

2. for the version with the actual estimate of the VAT gap - including all actions aimed at reducing tax evasion - there was also a decline by $2.9 \%$ in the tax gap (the tax gap decreased from $24.12 \%$ to $21.22 \%$, i.e., from CZK 105,508 mil. to CZK 94,108 mil.).

It is necessary to add that the tax collection and the decrease in the tax gap could have also been influenced, among others, by the total growth of GDP, cutback in carousel frauds, parts of which had been revealed by VAT control statements of the tax administration, the necessity to limit intentional tax evasion of taxable entities because of the implementation of VAT control statements.

In the calculations above, it is necessary to emphasize that the amount resulting from the additional assessments of VAT is not a relevant indicator in terms of the benefit of the VAT control statement. The reason is the fact that a large part of tax audits was initiated significantly before the implementation of the VAT control statement and the mere act of completing the tax audit and recording the corresponding additional assessment into the database do not show the benefits of the VAT control statement. Also, it can be assumed that a large part of complex carousel fraud control could have started in mid-2016 and the VAT control statement was introduced in 2016. VAT carousel frauds often have an intracommunity dimension and cooperating in the international exchange of information may be of a longer-term nature. This implies that a lot of operations that would affect the reporting, for example, of additionally assessed tax from a tax audit, will enter their values related to the VAT collection in subsequent periods. The values of additionally assessed tax from tax audits are used in this paper to make the comparison of complex theoretical fiscal revenue with the previous year of 2015 possible. In the case of processes to remove doubts, there is already a higher probability of correlation with the VAT control statement, therefore, together with the calls for the VAT control statements and reasons to initiate inspections arising from pairing of the VAT control statements, they will be the subject of subsequent processing. As there was no VAT control statement in 2015, only the recorded data from 2016 are included in the comparison. The authors assume that if there was no fiscal revenue from the above-mentioned 
XVI: Output values of analyzed indicators (in mil. of CZK, in \%)

\begin{tabular}{lcccc}
\multicolumn{1}{c}{ Indicator } & 2015 & 2016 & Development of value & Development of percentage \\
\hline GDP & $4,595,783$ & $4,773,240$ & $\uparrow 177,457$ & $\uparrow 3.9$ \\
VAT collection & 331,836 & 349,460 & $\uparrow 17,624$ & $\uparrow 5.3$ \\
VAT gap & 105,508 & 94,108 & $\downarrow 11,400$ & - \\
\hline VAT gap (in \%) & 24.12 & 21.22 & - & $\downarrow 2.9$ \\
\hline
\end{tabular}

Source: own processing using the data from the Czech Statistical Office, 2018

tools, the VAT gap would be higher. The sum of PRD and calls for VAT control statement together with the reasons to initiate inspections amounts to CZK 5,326 million. (The number of processes to remove doubts without the tax control statement account for 4,872. The number of calls for VAT control statements and reasons to initiate inspections come to 454 .)

Based on the above-mentioned data, it can be stated that

- calls for changing, completing, or confirming VAT control statements,

- reasons to initiate inspections arising from pairing of the VAT control statements and

- processes to remove doubts,

have resulted in the nationwide fiscal revenue from the value added tax amounting to CZK 5,326 million, which accounts for $5.66 \%$ in the total estimated tax gap for 2016 - these results confirm Hypothesis 2 defined in the Materials and Methods.
Therefore, the theoretical impact of the VAT control statement on the elimination of tax evasion could be quantified by estimating the VAT gap for 2015 and 2016 - see Tab. XVI.

From the above table, the correlation between the growth of gross domestic product and tax collection can be deduced. The calculated value of the gap is a positive indicator, also with respect to the "novelty" of the institute of VAT control statement.

The actual influence of the VAT control statement will be relevant to evaluate after some time in the on-coming years. As this paper is based on the data for 2016, which was the year of the introduction of the institute of VAT control statement, it can be expected that there will be a gradual increase in the revenue from VAT control statements and also from tools used to detect cases affecting the elimination of tax evasion.

\section{CONCLUSION}

Based on the obtained data on the tax change which can be deduced from the additional tax returns submitted in connection with the sent calls for VAT control statement and tax returns submitted thanks to the reasons to initiate inspection, the fiscal revenue from the VAT control statement for the Tax Office for the Olomouc Region was determined in the total amount of CZK 28 million for 2016. From the subsequent theoretical recalculation according to the generated calls for VAT control statements and reasons to initiate inspection in the entire Czech Republic, a tax change amounting to CZK 454 million was determined (knowing that the actual figures may differ from this generalization). In the next step the amount of additionally assessed tax from tax audits and revenue from processes to remove doubts were taken into account, for which a decrease in the number of cases as well as in the amount of collection can be observed in 2016. A significant influence can be attributed to the investigation of discrepancies resulting from VAT control statements and complex carousel frauds. The total fiscal revenue for the Czech Republic amounts to CZK 17,782 million, including the additionally assessed tax. If only the value of processes to remove doubts, calls for VAT statement control and reasons to initiate inspection is considered, the tax change amounts to CZK 5,326 million. As the institute of VAT control statement should be assessed from a global point of view, i.e., including the potential, clearly non-quantifiable benefit (preventing the actual occurrence of tax evasion), it was necessary to assess it compared to the total VAT collection. For this purpose, an estimate of the value added tax gap was made. Determining the share of the selected tools of the financial administration related to the VAT control statement in the total tax collection, the authors have concluded that after the implementation of the VAT control statement in 2016 (possibly due to the influence of many other factors), there are a declining trend of the VAT gap in comparison with the previous year and the resulting increase in the total VAT collection (also with regard to the year-on-year comparison of the GDP development).

Depending on the number of pending cases instigated by the measures implemented following the VAT control statement becoming effective, the subsequent fiscal effect should be evaluated in the years-to-come. However, the selection of individual benefits may be difficult due to the parallel effect of both the VAT control statement and electronic sales records. 
Acknowledgements

This study consists of partial results of research project No. 2019B0010 - Czech Social System Fraud Rate Estimation and System Optimization Proposals, financially supported by the Internal Grant Agency (IGA) of the Faculty of Economics and Management, CULS Prague.

\section{REFERENCES}

ARLTOVA, M., PAVEL, J., TEPPEROVÁ, J. and ZÍDKOVÁ, H. 2020. What are Effective Measures against VAT Evasion? Evidence from the Czech Republic. Ekonomicky Casopis, 68(2): 147-167.

CANIKALP, E., UNLUKAPLAN, I. and CELIK, M. 2016. Estimating Value Added Tax Gap in Turkey. In: $13^{\text {th }}$ International Scientific Conference on Economic an $d$ Social Development (ESD). Barcelona, Spain, pp. 437-445.

CASE. 2013. Study to Quantify and Analyse the VAT Gap in the EU-27 Member States Final Report. Available at: http://ec.europa.eu/taxation_customs/resources/documents/common/publications/ studies/vat-gap.pdf [Accessed: 2016, January 20].

CASE. 2014. Update Report to the Study to Quantify and Analyse the VAT Gap in the EU-27 Member States. Available at: http://ec.europa.eu /taxation_ customs/resources/documents/common/publications/ studies/vat_gap2012.pdf [Accessed: 2016, January 20].

CASE. 2015. Study to Quantify and Analyse the VAT Gap in the EU Member States 2015 Report. Available at: http://ec.europa.eu/taxation_customs/resources/documents/common/publications/studies/vat_ gap2013.pdf [Accessed: 2016, January 20].

CHAN, S-G. and RAMLY, Z. 2018. The Role of Country Governance on Value-Added Tax and Inequality. E\&M Ekonomie a Management, 21(4): 79-93.

CZECH REPUBLIC. 2011. Act No. 456/2011 Coll., on the Financial Administration of the Czech Republic. Government of the Czech Republic.

CZECH STATISTICAL OFFICE. 2018. Gross domestic product - Time series of quarterly accounts indicators. Czech Statistical Office. [Online]. Available at: https://www.czso.cz/csu/czso/hdp_cr [Accessed: 2019, October 9].

DUŠEK, J. 2016. VAT 2016: Act with overviews [in Czech: DPH 2016: zákon s přehledy]. Praha: Grada.

FINANCIAL ADMINISTRATION. 2014. Information from the GFR on the obligation of VAT payers to notify the tax administrator of the account number of the payment service provider. Financial Administration. [Online]. Available at: http://www.financnisprava.cz/cs/dane/novinky/2013/ informace-gfr-k-povinnosti-platcu-dph-oz-774 [Accessed: 2020, January 9].

FINANCIAL ADMINISTRATION. 2018a. Data from the register of tax subjects. Financial Directorate. [Online]. Available at: http://www.financnisprava.cz/cs/dane/analyzy-a-statistiky/udaje-z-registrudanovych-subjektu [Accessed: 2020, January 21].

FINANCIAL ADMINISTRATION. 2018b. Data from the register of tax subjects. Financial Directorate. [Online]. Available at: http://www.financnisprava.cz/cs/dane/analyzy-a-statistiky/danova-statistika [Accessed: 2020, January 25].

FINANCIAL ADMINISTRATION. 2018c. Annual reports and activity information. Financial Directorate. [Online]. Available at: http://www.financnisprava.cz/cs/financni-sprava/financni-sprava-cr/ vyrocni-zpravy-a-souvisejici-dokumenty/ [Accessed: 2020, January 28].

FINANCIAL AUTHORITY FOR OLOMOUC REGION. 2017. Data acquired on the basis of the Request for Information pursuant to Act No. 106/1999 Coll., On Free Access to Information, as amended. Financial Authority for Olomouc Region.

GFŘ - GENERAL FINANCIAL DIRECTORATE. 2017. Information provided according to Act 106/1999 Coll. Official board of the GFŘ. Available at: http://www.financnisprava.cz/cs/financni-sprava/ generalni-financni-reditelstvi/uredni-deska-gfr/poskytnute-info-dle-zakona-106-1999sb/2016 [Accessed: 2020, February 11].

GFŘ - GENERAL FINANCIAL DIRECTORATE. 2018. The remission of fines for failure to submit a VAT control report remains the same for 2018. Financial Directorate. [Online]. Available at: https:// www.financnisprava.cz/cs/financni-sprava/pro-media/tiskove-zpravy/2017/Prominuti-pokut-zanepodani-KH-2018-zustava-stejne-8957 [Accessed: 2020, January 29].

HYBKA, M. and MALGORZATA, M. 2018. Collection Dilemmas and Performance Measures of the Value-Added Tax in Germany and Poland. International Journal of Management and Economics, 54(2): 110-121.

INŠTITÚT FINANČNEJ POLITIKY. 2012. Odhad straty príjmov z dane z pridanej hodnoty. Ministry of Finance of the Slovak Republic. [Online]. Available at: http:// www.finance.gov.sk/Components/ CategoryDocuments/s_LoadDocument.aspx?categoryId=8181\&documentId=7171 [Accessed: 2016, February 10]. 
KRISTOFIK, P., ISTOK, M. and NEDELOVA, G. 2017. Motives of Establishing of New Onshore and Offshore Companies by the Slovak Enterprises in 2014. Politicka Ekonomie, 65(2): 198-216.

KOSTAKOVA, T. and ZIDKOVA, H. 2015. VAT Gap in the Czech Republic and Slovak Republic. Ekonomický Časopis, 63(7): 705-717.

KRZIKALLOVA, K. and TOSENOVSKY, F. 2020. Is the Value Added Tax System Sustainable? The Case of the Czech and Slovak Republics. Sustainability, 12(12): 4925.

MF ČR - MINISTRY OF FINANCE OF THE CZECH REPUBLIC. 2015. Control statement = systemic assistance in the fight against VAT fraud. Available at: http://www.financnisprava.cz/assets/cs/ prilohy/d-seznam dani/Kontrolni_hlaseni_TK_20151222.pdf [Accessed: 2020, February, 02].

MF ČR - MINISTRY OF FINANCE OF THE CZECH REPUBLIC. 2017. Methodology for calculating the impact of the introduction of control reports and electronic records of sales. Information submitted in accordance with the request for information in 10/2017. MF ČR.

MORAVEC, L., HINKE, J. and KANKA, S. 2018. VAT Gap Estimation - Czech Republic Case Study. Politicka Ekonomie, 66(4): 450-472.

PARLIAMENT OF THE CZECH REPUBLIC. 2014. Amendment to the Value Added Tax Act - EU: Explanatory Memorandum. Parliamentary print 291/0, part No. 1/8 [Online]. Available at: https://www.psp.cz/ sqw/text/tiskt.sqw?O=7\&CT=291\&CT1=0 [Accessed: 2020 , February 08].

RECKON. 2009. Study to Quantify and Analyse the VAT Gap in the EU-25 Member States. Available at: http://ec.europa.eu/taxation_customs/ resources/documents/taxation/tax_cooperation/combating tax_fraud/reckon_report_sep2009.pdf [Accessed: 2016, February 05].

SEMERAD, P. and BARTUNKOVA, L. 2016. VAT Control Statement as a Solution to Tax Evasion in the Czech Republic. In: 19 $9^{\text {th }}$ International Conference Enterprise and Competitive Environment (ECE). Brno: Mendel University, pp. 417-423.

SEMERAD, P., RADVAN, M. and BARTUNKOVA, L. 2016. VAT Control Statement problematic aspects. In: $21^{\text {st }}$ International Conference on Theoretical and Practical Aspects of Public Finance 2016. Prague, Czech Republic: University of Economics, pp. 90-95.

STAVJAŇOVÁ, J. 2014. Value added Tax Gap in The Czech Republic. Acta Universitatis Agriculturae et Silviculturae Mendelianae Brunensis, 62(6): 1427-1436.

STŘÍLKOVA, R. and ŠIROKÝ, J. 2015. Changes in the VAT burden on expenses of selected households in the Czech Republic (2007-2013). In: 18 ${ }^{\text {th }}$ International Conference on Enterprise and the Competitive Environment. Brno, Czech Republic: Mendel University, pp. 842-851.

ŠIROKÝ, J. and STŘíLKOVÁ, R. 2014. Changes in the VAT Burden on Expenses of a Selected Household in the Czech Republic (2007-2012). 19 $9^{\text {th }}$ International Conference on Theoretical and Practical Aspects of Public Finance. Prague, Czech Republic: University of Economics, pp. 296-305.

VOLKOVA, J. and TOMANOVA, V. 2016. Control statement 2016: interpretation examples: a practical guide to new report [in Czech: Kontrolní hlášení 2016: výklad s př́klady: praktický průvodce novým hlášením]. Praha: VOX.

ZIDKOVA, H. 2014. VAT Gap in the Czech Republic. In: $19^{\text {th }}$ International Conference on Theoretical and Practical Aspects of Public Finance. Prague, Czech Republic: University of Economics, pp. 376-383.

ZIMMERMANNOVA, J., SKALICKOVA, J. and SIROKY, J. 2015. VAT as an Indicator of Economic Activity of Regions in the Czech Republic. In: 20 In International Conference on Theoretical and Practical Aspects of Public Finance. Prague, Czech Republic: University of Economics, pp. 296-301.

Contact information

Jana Hinke: hinke@pef.czu.cz (corresponding author)

Lukáš Moravec: lukasgm@gmail.com

Monika Borsiczká: monika.koseckova@gmail.com 
